\title{
Zoltán Szente, Fanni Mandák, Zsuzsanna Fejes (eds.) Challenges and Pitfalls in the Recent Hungarian Constitutional Development. Discussing the New Fundamental Law of Hungary (L'Harmattan 2015, 352 pages)
}

\author{
BY VIKTOR LŐRINCZ
}

\section{„WAS IST MIT MIR GESCHEHEN?” - WHAT HAPPENED TO ME?}

This writing appeared on a wall at the corner of the Wesselényi and Kertész streets in 2012 and disappeared some days ago. It belonged to a piece of street art showing Empress Elisabeth of Austria (also known as Sisi) with a male head and the quote is a reference on Sisi's last words and Gregor Samsa's first words in Franz Kafka's Metamorphosis. ${ }^{1}$ The initial answer to Sisi's question is simple; she was stabbed to death by Luigi Lucheni. The metamorphosis that occurred to Samsa is more complicated but also led to the end of his life; first as a human, and finally as a bug. Placing the actions of the Italian anarchist in a broader context also raise more questions about Sisi's death.

Some aspects of the metamorphosis of the Hungarian constitutional system remain mysterious and unknown despite the manifold of proposed framework of interpretation ranging from literature to empirical research. However, exceptional situations, like the battle for surgeons or the financial crisis for economists, offers a great opportunity to Hungarian and foreign constitutional lawyers to gain an insight into the function and mechanism of a constitutional body. Many Hungarian and international scholars are try to find the answer on the question "What happened to the Hungarian constitutional system?" This growing interest in the Hungarian Fundamental Law and interpretation is reflected in this present book which is a result of Italian and Hungarian co-operation and a seminar held in Rome on 8 October 2014.

The involvement of Italian scholars enables everyone to step back from the immediate scenarios and contemplating the Hungarian system from a greater distance. For example, Angela Di Gregorio (The Fundamental Law of Hungary in the European context) provides an almost innocent lecture of the Hungarian Fundamental Law and the decisions of the Constitutional Court. This approach fits into the postmodern tradition of the found text but also reflects some tendencies in Hungarian literature and politics concerning the representation of Hungarian specificities towards a foreign public. ${ }^{2}$

1 Because of the nature of this street art and the anonymity of the artists, see $<$ http://index.hu/ urbanista/2012/12/16/a_vilag_legfurabb_kozteri_alkotasa_sisirol_erzsebet_kiralyne_torz_portreja_a rola_elnevezett_varosre $>$ and $<$ http://index.hu/mindekozben/poszt/2016/05/12/eltuntettek_a_vilag_ legfurabb_sisi-abrazolasat_erzsebetvarosbol/> accessed 27 May 2016, are the only reliable sources. The last words of Sisi are slightly different according to Sztáray (1909) 249: "Was ist den jetzt mit mir geschehen?".

2 This refers to Antal Szerb's “A Martian's Guide to Budapest”, see Szerb (2015), and the warning at the beginning of the book against journalists. 
Nicola Lupo (What Hungarian Constitutional Experience Can Teach European Constitutionalism) seems to have accepted the idea that the adoption of the new Fundamental Law was necessary due to the provisional character of the 1989 constitution but he also provides some interesting theories about the shortcomings of the current situation. According to Lupo, too much emphasis is put on the "legal constitutionalism" and the building of a constitutional identity was neglected. Lupo also deals with the possible contagious character of the Hungarian example within the European Union. Therefore, the author outlines a possible framework based on the weaknesses of the European Union whilst recalling the case of Austria in 2000. It is interesting and useful to contrast this framework with the official standpoint of the actual Hungarian government and with the apprehension of the opposition. The parallel is drawn with Italy, especially with Berlusconi's era, and this can also enrich the understanding of the ideological and technical background of the current Hungarian situation.

Fruzsina Gárdos-Orosz (Constitutional Amendments and their Judicial Review: the Case of Hungary), along with Lupo, analyse the difference between pouvoir constituant and pouvoir constitué and the judicial review of constitutional amendments. The concept of credible commitment from game theory will be highlighted instead of summarizing this paper alongside András Téglási's contribution (The Protection of Fundamental Rights in the Jurisprudence of the Constitutional Court of Hungary After the New Fundamental Law Entered into Force in 2012).

According to Gary J Miller: "Individuals are generally assumed to choose rationally in ways that make themselves better off. However, there are times when a political actor can benefit by denying himself or herself, early in a political interaction, the option of choosing self-serving actions later on. A general may know that retreat could be a valuable option in the future, but "burning one's bridges" may elicit more advantageous behavior from one's soldiers (or one's opponents). Constraining self-interested choice to induce beneficial actions from other players is called "credible commitment."

The organisational and symbolic separation of pouvoir constituant and constitué, for instance, is a possible basis for credible commitment. The constitutional values are safe if the costs of a new constitution or the amendment are high enough. However, the content of the constitution became "cheap talk" according to the terminology of game theory, if the existent parliamentary majority can vote in a new constitution or amend it without any limit. It would be interesting to see, how the different levels of commitment interacts beyond Gárdos-Orosz's pouvoir constituant and eternity clause, see e.g., Nóra Chronowski: The Fundamental Law Within the Network of Multi-Level European Constitutionalism, and Pál Sonnevend: The Role of International Law in Preserving Constitutional Values in Hungary - the Case of Hungarian Fundamental Law and International Law and the coercion (or lack of ) by adequate institutions.Numerous authors of the book deal with the "battle" between the Parliament and the Constitutional Court. This fight, in our opinion, shows how the credibility of the commitment was degraded by the adversaries. Maintaining the credibility of the commitment is also in interest of the government and its two-third majority. Ironically, the credible commitment of the Fundamental Law and its amendments was restituted by a minor and rather accidental event; the losing of the two-third majority at a by-election.

3 Miller (2011) 486. See also North and Weingast (1989) on the different but connected problem of "Ulysses pact" recently Orbán (2015) and also Cserne (2005). 
The book also contains papers with interesting methodological and interdisciplinary approaches. This was partly necessary due to some new phenomena in the Fundamental Law, like the National Avowal: the titlehas a problematic English translation. Horkay Hörcher, writing about the genre of the text, underlines the religious connection of the title "Nemzeti hitvallás", where "hitvallás" can refer to the Apostles' Creed, Nicene Creed, or to the Augsburg Confession. ${ }^{4}$ One of the main questions about the National Avowal, or National Creed or National Confession is the normative or rather symbolical character, we have to add that the Latin name of the Apostles' Creed is Symbolum Apostolorum or Symbolum Apostolicum. ${ }^{5}$ Balázs Fekete (The National Avowal: More than a Conventional Preamble to a Constitution) applies Speech Act Theory on the text, and also analyses how the new text create a new narrative instead the "invisible constitution" -a feature linked to the former, 1989 text. Zsuzsanna Fejes in "Constitutional Identity, the Historical Constitution Clause in the Hungarian Fundamental Law, and its Effects on Constitutional Interpretation" also deals with the new constraints of understanding. It is also interesting to observe this struggle toward an exclusive narrative in the 21th century, three decades after- the seminal book of Lyotard. ${ }^{6}$ On the other hand, it is no surprise that a constitution posit itself as the final stage of the constitutional history (recalling even older analogies than Lyotard), but this turns back to the problem of amendments. Balázs Fekete also incorporate the "Law and Emotions" approach in the analysis. The main problem with this approach is the rather unclear relation between the term "emotion" in law and in psychology in the underlying literature. ${ }^{7}$ The approach of András L. Pap (Who are "we, the people"? Biases and preferences in the Hungarian Fundamental Law) is marked by deconstruction and is also very exciting. Some might consider the finding of the $\mathrm{DWEM}^{8}$ in the Hungarian Fundamental Law a little belated approach but belatedness is just one characteristic of legal literature. Without diving into great details, we feel that the majority described by Pap is rather illusory and moreover, we do not want to dissimulate the suspicion, that instead of firm ideologies, the split in the Hungarian society can be described solely on the minimal group paradigm. ${ }^{9}$ This framework can explain the in-group favouritism, intergroup bias, excess cooperation and excess conflict of the contemporary constitutional scene of Hungary. Giuseppe Franco Ferrari (The Controversial Definition of Hungarian Identity: from the Preamble to the Role of the New Constitutional Court) sets the debate on the Preamble in an international context.

The empirical approach in law is also currently fashionable. Fanni Mandák, along with Ákos Cserny (Hungarian Governmental Operation from an European View) analyse the role and place of the Hungarian Government within the constitution Fanni Mandák also uses empirical data (Sign of Presidentialisation in Hungarian Government ReformsChanges After the New Fundamental Law). The approach is interesting but there are some shortcomings in the text including double visualisation of the same data (Diagram 1. and Diagram 2.); calculation errors in Table 2. (2011); problems with the $\mathrm{x}$-axis in Diagram 3

${ }^{4}$ Horkay Hörcher (2012) 288-90.

5 Lörincz (2014) 252. See also Röhrig (1962).

${ }^{6}$ Lyotard (1979).

7 Why do cornerstone publications on emotion and rationality, like Antonio Damasio (2005) have little or no impact on the law and emotion movement?

${ }^{8}$ I.e. like the criticism of the western culture based on the dominance of the Dead White Male/ Men, Pap also enumerates the ideal characteristic of the Hungarian Citizen.

9 Tajfel (1971). 
and the use of "significant" (page 164 for instance), as synonym of "big", without performing a significance test. ${ }^{10}$

Zoltán Szente also conducted an interesting analysis on the political orientation of judges of the Constitutional Court (The Decline of Constitutional Review in Hungary Toward a Partisan Constitutional Court?). The attitude-measurement approach can be traced to its psychological roots, like the case of emotions. ${ }^{11}$ This brings into questionthe use of terms in interdisciplinary research. The psychology use numerous tools in order to measure attitudes $^{12}$ but the basic assumptions of these methods are far from the settings of the present paper, partly because it is impossible to perform such tests involving judges of the Constitutional Court. In order to avoid this confusion, Zoltán Szente uses "orientation" instead of "attitude" Another question is the separation of the conclusions drawn from the model and deductions from elsewhere. Should outliers be erased and explanatory power be measured on the basis of the empirical model or by involving other arguments? Also, the use of the strict structure of an empirical article probably seems strange for a lawyer but it could facilitate the reading of the paper by experts from the field of empirical sciences. Cesare Pinelli (Populism and Illiberal Democracies: The Case of Hungary), underlines the differences between Zoltán Szente's and Péter Paczolay's clear and well-structured paper: The Transformation of the Constitutional Court in Hungary.

In conclusion, the book unites many different approaches and opinions and by deliberating the arguments, the public can draw an autonomous conclusion from it. Beside the content and method, the reader is encouraged to pay attention to the linguistic subtleties; the book is a step further toward the establishing of Hungarian constitutional legal terminology. This road marked sometimes by pitfalls, but beyond doubt, it is a great challenge.

\section{LITERATURE}

Cserne, P., 'Államelmélet és játékelmélet. Miről szól az alkotmány közgazdaságtana? [Game Theory and the Theory of the State. An Outline of Constitutional Economics]' in B. Fekete, S. Szabó (eds), Monumentum aere perennius. Tanulmányok Péteri Zoltán tiszteletére [Studies in Honour of Zoltán Péteri] ([Magyar Összehasonlító Jogi Egyesület 2005) 53-69.

Damasio, A. R., Descartes' Error: Emotion, Reason, and the Human Brain (Penguin 2005)

Horkay Hörcher, F., 'A Nemzeti hitvallásról'[On the National Avowal] in A Jakab, A Körösényi (eds), Alkotmányozás Magyarországon és máshol [Constitution-making in Hungary and elsewhere] (Új Mandátum Kiadó 2012) 287-309

Kafka, F., Die Verwandlung (Verlag der Weißen Bücher 1915)

Krosnic, J. A., Judd, C. M., Wittenbrink, B., 'The Measurement of Attitudes' in D Albarracín, BT Johnson, MP Zanna (eds), The Handbook of Attitudes (Lawrence Erlbaum Associates, Inc, Publishers 2005) 21-76.

Lőrincz, V., 'La symbolique juridique de la «Porta speciosa » de La cathédrale archiepiscopale d'Esztergom en Hongrie au XIIe siècle' in B Fourniel (ed), La justice dans les cités épiscopales du Moyen Âge à la fin de l'Ancien Régime (PU Toulouse 1-Capitole 2014) 241-260.

Lyotard, J. F., La condition postmoderne. Rapport sur le savoir (Editions de Minuit 1979)

Miller, G. J., 'Credible Commitment' in B Badie (ed), International Encyclopedia of Political Science (Sage 2011) 486-488.

10 Wasserstein and Lazar (2016).

11 E.g. Segal and Spaeth (2002) 89-91.

12 Cf. for instance Krosnic, Judd, Wittenbrink (2005). 
North, D. C., Weingast, B. R, 'Constitutions and Commitment: The Evolution of Institutions Governing Public Choice in Seventeenth-Century England' (1989) 49 The Journal of Economic History 803-832.

Orbán, E., 'Az Alkotmányjog gazdasági elemzése - áttekintés' [Economic Analyse of the Constitutional Law - An Outline] (2015) 56 Állam- és Jogtudomány 7-23.

Röhrig, F., 'Rota in Medio Rotae. Ein Typologischer Zyklus Aus Österreich' (1962) 2 Jahrbuch des Stiftes Klosterneuburg 7-113.

Segal, J. A., Spaeth, H. J., The Supreme Court and the Attitudinal Model Revisited (Cambridge University Press 2002)

Szerb, A., A Martian's Guide to Budapest (Magvetö Könyvkiadó 2015)

Sztáray, I., Aus den letzten Jahren der Kaiserin Elisabeth (Wien : A Holzhausen 1909)

Tajfel, H. et al, 'Social Categorization and Intergroup Behaviour' (1971) 1 European Journal of Social Psychology 149-178.

Wasserstein, R. L., Lazar, N. A., 'The ASA's Statement on P-Values: Context, Process, and Purpose' (2016) 2 The American Statistician 129-133. 